Beata K. Obsulewicz

(Katolicki Uniwersytet Lubelski Jana Pawła II)

\title{
StanisŁaw Fita i BolesŁaw Prus
}

StanisŁaw Fita, kreśląc sylwetkę Feliksa Araszkiewicza, swego akademickiego nauczyciela i opiekuna naukowego, zanotował:

Zainteresowania naukowe prof. Araszkiewicza obejmowały literaturę polską okresu pozytywizmu i Młodej Polski. [...] Główny jednak przedmiot jego badań stanowiła osoba i dzieło Bolesława Prusa. Problematyka pierwszej pracy naukowej [...] wytyczyła kierunek zainteresowań badawczych na dalsze lata. Większość bowiem studiów o autorze Lalki stanowi opis i interpretację jego myśli filozoficzno-etycznej. Tego rodzaju wypowiedzi tropił Araszkiewicz $\mathrm{w}$ trakcie poszukiwań nieznanych materiałów rękopiśmiennych. ${ }^{1}$

Warto zatrzymać się chwilę nad tymi paroma uwagami, które w dużej mierze odnieść można także do osoby ich autora. Pozwalają bowiem wskazać pierwszy ważny rys Profesora Fity prusologa. Spotkanie z twórczością Prusa miało miejsce dzięki Araszkiewiczowi, w trakcie studiów polonistycznych w Katolickim Uniwersytecie Lubelskim. Podobnie jak jego mistrza (nie ostatniego na drodze badań nad Prusem, o czym jeszcze przyjdzie wspomnieć), Profesora cechowała autentyczna pasja naukowa. Raz podjęte tematy i problemy, mimo ich uważnego oglądu poświadczonego publikacjami naukowymi, uważał za zagadnienia „stale otwarte”, chciał i lubił do nich powracać, najczęściej z zamiarem obejrzenia ich pod innym kątem, uzupełnienia, niekiedy sprostowania. Także dla profesora Fity zainteresowanie Prusem oznaczało wytyczenie głównego kierunku zainteresowań na dalsze lata oraz w znacznej mierze sprofilowanie jego kariery naukowej i akademickiej. Poszukiwanie i kompletowanie spuścizny po Prusie (korespondencja, publicystyka), a także wieloletnie kolekcjonowanie wszelkich przekazów związanych z życiem i twórczością autora Lalki uczyniły go tym, kim zapamiętało go (i pewnie długo jeszcze będzie go tak pamiętać) środowisko polonistów: jednym z najwybitniejszych, o ile nie najwybitniejszym, biografem Aleksandra Głowackiego. Jego nazwisko jednym tchem wymienia się wraz z osobami Zygmunta Szweykowskiego, Edwarda Pieścikowskiego czy Józefa Bachórza i nie ma chyba w Polsce (a śmiem przypuszczać, że i poza nią) nikogo, kto mógłby je pominąć w rzetelnych badaniach nad postacią i dziełem twórcy Placówki. Bez wątpienia wspomniani wyżej literaturoznawcy przyczynili się do określenia miejsca i roli Prusa na współczesnej mapie historii literatury powszechnej. Patrząc na dorobek lubelskiego historyka literatury, nie popełni się błędu, stwierdzając, że Prus wyznaczał na pewno najważniejszy obszar badawczy Profesora. On też był drogą Fity w wiek XIX. Namysł nad rozległym kompleksem tematów, ewokowanych przez twórczość Prusa, uczulił go też na zjawiska najważniejsze dla kultury polskiej i życia społecznego w XIX

1 S. Fita, Feliks Araszkiewicz (14 stycznia 1895 - 30 maja 1966), „Pamiętnik Literacki” 1966, z. 4, s. 704. 
wieku i - być może - w wieku XX. Mało odkrywcze jest w tym miejscu strawestowanie znanego powiedzenia, ale może warto się go dopuścić: „kto Prusa (dziennikarza, publicystę, polemistę, pisarza, społecznika, podróżnika) przeżył, ten wiele przeżył”. To w dużej mierze zasługa autora Omyłki, że Profesor stał się jednym z najpoważniejszych badaczy życia literacko-społecznego w XIX wieku, prasoznawcą, edytorem, organizatorem życia kulturalnego, spiritus movens konferencji i wieloautorskich publikacji pokonferencyjnych, wychowawcą prusologów (jako recenzent prac doktorskich i habilitacyjnych, promotor doktoratu).

Jak wiadomo, Bolesław Prus za najważniejszy ideał spośród ideałów życiowych uważał użyteczność, a z nią wiązał między innymi wymianę usług. Idąc tropem tego założenia, może warto także rozważyć, jakie korzyści z prac Profesora stały się udziałem Prusa?

Pierwszą z nich jest na pewno ponowne wpisanie Aleksandra Głowackiego w literacki krajobraz Lubelszczyzny i zaakcentowanie jego związków z „małą ojczyzną”. Tu szereg dokonań Profesora jest długi: jedno z jego pierwszych wystąpień naukowych w roku 1958 to Lublin i Lubelszczyzna w życiu i twórczości Bolesława Prusa². $\mathrm{Z}$ pozoru mogłoby się wydawać, że to zagadnienie oczywiste i proste w opracowaniu, ale jak dowodzą obecne kwerendy archiwalne, prowadzone po sześćdziesięciu latach od tamtego czasu - nadal [sic!] nie wszystko o czasie mieszkania i pobierania nauk w Lublinie wiadomo, podobnie jak o okresie puławskim, przyjaciołach i bliskich Prusa w Lublinie etc. Tę „regionalną” wiedzę Profesor systematycznie poszerzał, uzupełniał i prezentował, choć - należy to przypomnieć - nie on opracował w publikacji Bolesław Prus (1842-1912). Kalendarz życia i twórczości najwcześniejsze lata życia przyszłego autora Faraona, lecz Krystyna Tokarzówna ${ }^{3}$. W ciągu wielu lat studiów nad Prusem Profesor poświęcał uwagę miejscom, które w życiu i twórczości Głowackiego zapisały się w sposób szczególny. Tak więc wypowiadał się o Hrubieszowie ${ }^{4}$, miejscu narodzin Prusa; o Lubartowie ${ }^{5}$, gdzie bywał on w latach wczesnej młodości; o ludziach i tajemnicach Prusowskiego Kazimierza (np. ostatnim z kazimierskich reformatów, o. Adrianie Gałuszkiewiczu, uwiecznionym w opowiadaniu $Z \dot{z} y$ wotów świętych) ${ }^{6}$. Profesor chętnie współpracował

2 S. Fita, Lublin i Lubelszczyzna w życiu i twórczości Bolesława Prusa, „Sprawozdania z Czynności Wydawniczej i Posiedzeń Naukowych Towarzystwa Naukowego KUL za lata 1953-1956" 1958, nr 7, s. 197-202.

3 Bolesław Prus 1847-1912. Kalendarz życia i twórczości, oprac. K. Tokarzówna i S. Fita, red. Z. Szweykowski, Warszawa 1969. Tokarzówna przygotowała też książkę Młodość Bolesława Prusa (Warszawa 1981).

4 S. Fita, Bolesław Prus i jego ziemia rodzinna, „Biuletyn Towarzystwa Regionalnego Hrubieszowskiego" 1998, s. 8-12.

5 S. Fita, Bolesław Prus a Lubartów, „Lubartów i Ziemia Lubartowska” 1959, s. 11-12.

6 S. Fita, Wśród ludzi i tajemnic Kazimierza, w: Na pozytywistycznej niwie, red. T. Lewandowski, T. Sobieraj, Poznań 2002, s. 157-164. 
z lokalnymi środowiskami i regionalnymi periodykami . Biorąc udział w podejmowanych przez nie staraniach, by celebrować pamięć o Prusie, nie lekceważył, wzorem kronikarza, żadnego dobrego dzieła podjętego na tak zwanej prowincji. Specjalne studium zadedykował też „Lublinowi pozytywistów”, wśród których nie mogło zabraknąć Jana w Oleju i jego szkolnych oraz popowstańczych perypetii ${ }^{8}$. Najwięcej miejsca naturalnie poświęcił związkom Prusa z Nałęczowem. Troska o to, by „żywe wspomnienie” o pisarzu w Nałęczowie utrwalić, należała do jego priorytetów. Do tematów nałęczowskich w twórczości pisarza wracał wielokrotnie, z wyraźną lubością. Interesowały go zawiązywane w czasie wakacyjnych miesięcy relacje, spotkani ciekawi ludzie, tryb spędzania wakacji (z żoną lub bez niej, na spacerach i wycieczkach oraz przy „piśmiennych robotach”, np. nad zagadnieniami kompozycji), powzięte z miejscowych obserwacji wątki w kronikach, zaangażowanie w sprawy społeczności nałęczowskiej zwłaszcza w roku 1905 (wspieranie dynamicznie wówczas rozwijających się inicjatyw społecznych), starania o podniesienie poziomu higieny, związki z Oktawią i Stefanem Żeromskimi etc. Sporo uwagi poświęcił zweryfikowaniu legend o nałęczowskiej genezie słynnych powieści (Placówka, Lalka, Emancypantki), ustalając fakty na podstawie zachowanych dokumentów; wieści niepełne doprecyzowywał lub korektował ${ }^{9}$. Szczególnym wkładem Fity w upamiętnienie i utrwalenie pamięci o Prusie jest znaczny udział w zorganizowaniu Muzeum Bolesława Prusa, jedynego takiego w Polsce. Starania o jego powołanie zostały zainicjowane przez Feliksa Araszkiewicza w 1954 roku. Magister Stanisław Fita, wówczas asystent na KUL, o planach informował na łamach czasopism polonistycznych ${ }^{10}$. Dzielił się problemami w zdobywaniu eksponatów i pamiątek po pisarzu, który i w tym podzielił los umiłowanej Warszawy, że w czasie II wojny światowej bezpowrotnej stracie, wraz ze zniszczeniem miasta, uległy jego rzeczy osobiste, znaczna część korespondencji. Informował o pozyskanych depozytach, darach przekazanych tworzonym zbiorom muzealnym, wsparciu miejscowych władz administracyjnych. Muzeum zostało otwarte 3 XII 1961 roku w salach Pałacu Małachowskich, scenariusz ekspozycji opraco-

Zob. S. Fita, Prus-publicysta [w 125. rocznicę urodzin i 6o. rocznicę śmierci Bolesława Prusa, Hrubieszów 28 X 1972], „Biuletyn Towarzystwa Regionalnego Hrubieszowskiego” 1980, nr 4, s. $16-22$.

8 S. Fita, Lublin pozytywistów, „Akcent” 1999, nr 2, s. 78-89. Zob. też: S. Fita, Kartka z lat szkolnych Bolesława Prusa, „Kamena” 1959, nr 22, s. 2, 11; S. Fita, [komentarz w:] B. Prus, Notatki $z$ Lublina, Lublin 1974 [druk bibliofilski].

9 Zob. S. Fita, Prus w Nałęczowie, „Zeszyty Naukowe KUL” 1962, nr 2, s. 105-114; S. Fita, Bolesław Prus i jego ziemia rodzinna, „Głos Nałęczowa” 1998, s. 13-14; S. Fita, „Żywe wspomnienie Prusa...”, w: tegoż, „Pozytywista ewangeliczny”. Studia o Bolesławie Prusie, Lublin 2008, s. $339-351$.

S. Fita, Muzeum Bolesława Prusa w Nałęczowie [Lublin 1961], k. nlb 12; S. Fita, Nałęczowskie Muzeum Prusa, „Więź” 1961, nr 4, s. 152-154; S. Fita, Muzeum Bolesława Prusa w Nałęczowie, „Ruch Literacki” 1962, nr 2, s. 102-103. 
wali mgr Irena Iskrzycka, dyrektor Muzeum Lubelskiego i mgr Stanisław Fita ${ }^{11}$. Wedle zamysłów projektodawców miało ono nie tylko poświadczać związki Prusa $z$ kurortem, ale także inspirować do pogłębiania znajomości twórczości pisarza. Profesor, o czym nie należy zapominać, bacznie obserwował działania obu muzeów nałęczowskich (także tzw. „chaty” Żeromskiego) ${ }^{12}$. Wiernie towarzyszył ich funkcjonowaniu, wielokrotnie wygłaszał w nich odczyty i prelekcje ${ }^{13}$. W „Głosie Nałęczowskim” uczcił też pamięć Krystyny Tokarzówny, wespół z którą przygotował kalendarium i której inne prace „prusologiczne” śledził z wielką życzliwością ${ }^{14}$. Nie od rzeczy będzie też odnotowanie, że dzięki ofiarnym staraniom Fity Lublin stał się ważnym ośrodkiem badań nad Prusem. Tradycje zapoczątkowane przez Araszkiewicza kontynuował na KUL, kształcąc młodych prusologów, z których wymienić trzeba zwłaszcza śp. Jakuba Malika (1970-2017) ${ }^{15}$. Do prac edytorskich przygotował ks. dra Jacka Nowaka (wydawcę dwóch tomów korespondencji Prusa) ${ }^{16}$ i dr Joannę Lekan-Mrzewkę (edytorkę nowel ${ }^{17}$ i kronik). Z wielką radością powitał projekt Edycji Krytycznej Pism Wszystkich Bolesława Prusa (grant NPRH) i wszedł do komitetu Edycji. Na jego seminarium doktorskim powstała dysertacja poświęcona Prusowi ${ }^{18}$. Umiejętnie nawiązywał i harmonijnie prowadził pracę z drugim uniwersyteckim ośrodkiem lubelskim, czyli UMCS. $Z$ prof. Eugenią Łochową ${ }^{19} \mathrm{i}$ prof. Marią Woźniakiewicz-Dziadosz ${ }^{20}$ organizował konferencje, zmieniające się w prawdziwe sympozjony (zwłaszcza w Domu Pracy Twórczej KUL w Kazimierzu Dolnym, tzw. Rajchertówce), które potem owocowały pokonferencyjnymi artykułami. Skoro już mowa o zasługach Profesora dla rozwoju nauki polskiej, należy przypomnieć o recenzjach "prusologicznych” rozpraw doktorskich ${ }^{21}$ i dysertacji z dalszych etapów rozwoju naukowego ${ }^{22}$. A także o wie-

11 S. Fita, Prus w Nałęczowie, „Zeszyty Naukowe KUL” 1962, s. 114.

12 S. Fita, Dwa muzea nałęczowskie, „Poradnik Bibliotekarza” 1966, nr 6, s. 176-177.

13 S. Fita, „Żywe wspomnienie Prusa”. Na 25-lecie Muzeum Bolesława Prusa w Nałęczowie, „Głos Nałęczowa" 1986, s. 14, 16-17, 24.

14 S. Fita, Na szlakach Bolesława Prusa, Wspomnienie o Krystynie Tokarzównie, „Głos Nałęczowa" 2001, s. 22.

15 J.A. Malik, „Lalka”. Historie z różnych światów, Lublin 2005.

16 B. Prus, Korespondencja, t. 1: Listy Bolesława Prusa, oprac. ks. J. Nowak, Warszawa-Lublin 2017. W przygotowaniu t. 2: Listy do Bolesława Prusa.

17 J. Lekan-Mrzewka, W walce z życiem, Miłość ubogiego młodzieńca, Bądźmy ostrożni, Na Bielanach, w: B. Prus, Humoreski, nowele, opowiadania, t. 4 (1876-1877) i 5 (1878-1879), Warszawa-Lublin 2017.

18 A. Janke, Interakcje w świecie bohaterów powieści współczesnych Bolesława Prusa (praca doktorska 2007).

19 Bolesław Prus. Twórczość i recepcja, red. E. Łoch, S. Fita, Lublin 1993.

20 Bolesław Prus: pisarz, publicysta, myśliciel, red. M. Woźniakiewicz-Dziadosz, S. Fita, Lublin 2003.

21 M. Gloger, Światopogląd Bolesława Prusa (2002), M. Rumińska, „Wieczny karnawał”. Bolesława Prusa wizja społeczeństwa (2007), S. Karpowicz-Słowikowska, Kwestia niemiecka w publicystyce Bolestawa Prusa (2008).

Profesor opiniował prace T. Budrewicza, E. Paczoskiej, B. Bobrowskiej. 
lu artykułach naukowych poświęconych Prusowi, których był życzliwym, ale i bardzo pedantycznym (w najlepszym sensie tego słowa) recenzentem.

Bezsprzecznie najistotniejszym dziełem Profesora jest opracowany wespół z Krystyną Tokarzówną, pod opieką drugiego z naukowych opiekunów i mistrzów Stanisława Fity - Zygmunta Szweykowskiego - tom Bolesław Prus 1847-1912. Kalendarz życia i twórczości ${ }^{23}$. Przygotowania do tak monumentalnego dzieła musiały rozpocząć się dużo wcześniej i z nimi wiązać należy kwerendę, której efektem stała się publikacja Listów Aleksandra Głowackiego (B. Prusa) w opracowaniu Tokarzówny ${ }^{24}$ oraz Wspomnień o Bolesławie Prusie opracowanych przez Fitę ${ }^{25}$.

Zebrana epistolografia doczekała się recenzji Profesora. Rozpoczął ją w tonie minorowym: „,...] biorącemu wspomniany tom do ręki nasuwa się od razu jedno żałosne spostrzeżenie - jakże mało listów pisarza [...] zachowało się do dziś" ${ }^{26}$. Charakteryzował następnie ich grupy tematyczne i utyskiwał, że tak niewiele (w porównaniu z innymi twórcami) w listowych notatkach wiadomości o tekstach literackich autorstwa Prusa. Doceniając trud edytorki (odnalezienie i skomentowanie zapisów oraz zaopatrzenie tomu w bogaty materiał ilustracyjny), dorzucał garść uzupełnień, parę drobnych sprostowań i marzenie/ zalecenie, by na drodze mozolnych i wytrwałych kwerend dążyć do zebrania jak największej ilości (być może zachowanego) materiału listowego i w przyszłości myśleć o publikacji listów Prusa i nadsyłanych do niego. Sam postępował zgodnie z tą wytyczną. Przez całe życie poszukiwał niedrukowanej korespondencji i ją sukcesywnie w prasie polonistycznej publikował. I tak, dzięki jego staraniom, znamy: Nieznany nałęczowski list Bolesława Prusa [do Władysławy i Juliana Adolfa Święcickich z 1 IX 1905] ${ }^{27}$, relację Bolesław Prus i Henryk Struve. (Z niedrukowanej korespondencji) ${ }^{28}$, nieznane listy Prusa ze zbiorów Heleny Porębskiej z Gdańska i Jerzego Dunin-Borkowskiego z Krośniewic koło Kutna ${ }^{29}$, nowe listy do Bolesława Prusa oraz nowe listy

23 Profesor opracował w nim okres od 1 kwietnia 1883 do 19 maja 1912 roku.

24 A. Głowacki (B. Prus), Listy, oprac. K. Tokarzówna, Warszawa 1959.

25 Wspomnienia o Bolestawie Prusie, oprac. S. Fita, Warszawa 1962.

26 S. Fita, Listy Bolesława Prusa, „Twórczość” 1960, nr 3, s. 139-142.

27 S. Fita, Nieznany natęczowski list Bolesława Prusa, „Kamena” 1963, nr 15/16, s. 3.

28 S. Fita, Bolesław Prus i Henryk Struve. (Z niedrukowanej korespondencji), „Przegląd Humanistyczny" 1964, nr 2, s. 143-148.

29 S. Fita, Nieznane listy Bolesława Prusa, „Ruch Literacki” 1961, nr 4/5, s. 218-220. Znalazła się tam informacja, że w 1925 roku Zakład Leczniczy w Nałęczowie wypożyczył od Marii Jakowskiej, żony byłego prezesa uzdrowiska dra Mariana Jakowskiego, 35 listów Prusa do niej pisanych. Pani Jakowska, mieszkając poprzednio w Nałęczowie, należała do bliskich przyjaciół Oktawii Żeromskiej, wśród których znajdował się też Aleksander Głowacki. Profesor wystąpił z propozycją odnotowania (w przyszłości, gdy listy będą powtórnie wydawane) wśród korespondentów nazwiska Marii z Wiszniewskich Jakowskiej. Świadczy to o badawczej czujności i trosce o maksymalną użyteczność prowadzonych przez niego studiów. 
Prusa (opracowane wspólnie z Tokarzówną) zamieszczone w 19. tomie Archiwum Literackiego $^{30}$ oraz nieznany list do Henryka Ułaszyna ${ }^{31}$.

Wspomnienia o Bolesławie Prusie sam tak prezentował w krótkim posłowiu:

[Są to w sumie 53 jednostki] publikowane w czasopismach, księgach zbiorowych, fragmenty z dzienników i pamiętników osób współczesnych pisarzowi. Wydawca nie miał ambicji zebrania i ogłoszenia wszystkich dostępnych relacji wspomnieniowych [...], spośród obfitego materiału dokonano wyboru najbardziej wiarygodnych [...]. Bezpośrednio po tekście każdego wspomnienia zamieszczano informacje biograficzne o autorze oraz notkę proweniencyjną tekstu. Najdokładniejsze notki biograficzne otrzymywali - o ile to było możliwe - autorzy mniej znani. Komentarz zawiera wyjaśnienia i sprostowania faktów dotyczących osoby Prusa. Odwoływano się [...] przede wszystkim do wypowiedzi samego pisarza. Starano się także [...] skonfrontować realia z innymi źródłami [...]. Podano również wyjaśnienia mniej znanych realiów oraz informacje o osobach występujących w danym wspomnieniu. ${ }^{32}$

Te materiały źródłowe również starał się sukcesywnie uzupełniać. Zatem dołączył Karola Zakrzeńskiego wspomnienie o Prusie ${ }^{33}$ oraz Nieznane wspomnienie Janiny Bemówny o Bolestawie Prusie ${ }^{34}$.

Kalendarz życia i twórczości - właściwie nawet życia przed życiem (genealogia rodziny) i po nim (relacja z pogrzebu) - stanowi do dziś pozycję niezbędną w księgozbiorze każdego miłośnika i badacza XIX wieku. Wraz z poczynionymi uzupełnieniami ${ }^{35}$ jest punktem wyjścia i niezastąpionym punktem odniesienia dla każdego prusologa. Dzieło doczekało się wnikliwych, ważnych recenzji, z których w tym miejscu przywołana zostanie tylko jedna. Edward Pieścikowski nazwał je summa prusologiae i tak swe stanowisko argumentował:

„Prus nie ma biografii, należy do najszczelniej zakonspirowanych pisarzy, bo nawet oczy jego na portretach kryją się za ciemnymi szkłami”. Można by efektownie powiedzieć, że zacytowane sformułowanie Tadeusza Boya-Żeleńskiego straciło wieloletnią aktualność: stało się to za przyczyną Kalendarza życia i twórczości Bolesława Prusa, opracowanego przez Krystynę Tokarzównę i Stanisława Fitę pod naukowa redakcją Zygmunta Szweykowskiego; stało się to więc za sprawą publikacji liczącej stron bez mała dziewięćset. Imponujące osiągnięcie, wspaniały rezultat pracowitości, okazały wynik dociekliwości, sui gneris talentu.

Przed autorami właśnie tego kalendarium stanęło zadanie szczególnie trudne: dekonspi-

30 S. Fita, Listy do Bolesława Prusa, Archiwum Literackie, t. 19: Bolesław Prus. Materiały, red. E. Pieścikowski, Wrocław 1974, s. 185-243; Nowe listy Bolesława Prusa, oprac. S. Fita, K. Tokarzówna w: jw., s. 166-183.

31 S. Fita, „Notatki wołyńskie” Bolesława Prusa i jego nieznany list do Henryka Ułaszyna, w: Od średniowiecza do współczesności. Prace ofiarowane Jerzemu Starnawskiemu, red. J. Okoń, M. Kuran, Łódź 200o, s. 388-392.

32 S. Fita, Posłowie, w: Wspomnienia o Bolesławie Prusie, oprac. S. Fita, Warszawa 1962, s. 283284.

33 Karola Zakrzeńskiego wspomnienie o Prusie, oprac. S. Fita, w: Archiwum Literackie, t. 19, s. $235-242$.

34 Nieznane wspomnienie Janiny Bemówny o Bolesławie Prusie, do druku podał S. Fita, „Głos Nałęczowa" 1997, s. 13-14.

35 S. Fita, Aneks do „Kalendarza życia i twórczości” Bolesława Prusa, w: Archiwum Literackie, t. 19 , s. $243-285$. 
rowali przecież - miał Boy-Żeleński rację - jedną z najszczelniej „zamkniętych” biografii. Tokarzówna i Fita piszą o tym szczerze w końcowej Nocie, narzekając na prawie zupełny brak materiałów autobiograficznych (brak pamiętnika, bogatej i instruktywnej korespondencji). W tej sytuacji źródłem niejako zastępczym była twórczość literacka pisarza, zwłaszcza jego Kroniki i publicystyka; źródłem natomiast podstawowym - poza archiwaliami dla okresu wczesnego - była prasa. Autorzy stwierdzali lapidarnie, że „przejrzano prasę codzienną i tygodniową z tego okresu”, dalej wymieniają blisko trzydzieści dzienników i czasopism, które materiału przyniosły najwięcej. Zwięzły meldunek, a kryje się za nimi trud zgoła benedyktyński. [...] Otrzymaliśmy zatem portret Prusa może nieco jednostronny, bardziej „publiczny” niż „prywatny”, ale przez to jakże trafny: autor Lalki na tle swoich czasów, w kontekście ówczesnej codzienności społeczno-politycznej i obyczajowej. Udało się Tokarzównie i Ficie ukazać w kalendarzu, właściwe - jakby określił Stanisław Pigoń - wzrost i wymiary Bolesława Prusa. [...] Nie poprzestali na rejestracji samych faktów (data - wydarzenie - źródło), ale rozszerzyli informacje o nich (m.in. cytując odnośne artykuły lub streszczając relację), nadto - uzupełnili komentarzem (przede wszystkim ustosunkowującym się do przekazów, motywującym nowe ustalenia). Ponieważ [...] kalendarz nie mógł być prostym zsumowaniem stanu badań nad życiem i twórczością Prusa, a Jest w ZnACZnym STOPNIU DZIEŁem WŁasNYCH - Tokarzówny i Fity - ROZSTRZYGNIĘĆ I ODKRYĆ, stąd rola szczególna wspomnianego komentarza. ${ }^{36}$

Jak się wydaje, wartością dodaną prac nad kalendarium (w dobrym duecie, pod znakomitą opieką naukową) była w przypadku Profesora Fity pogłębiona znajomość prasy i realioznawstwa pozytywistycznego, codzienności życia w XIX wieku i pierwszej tercji wieku XX. Ta wiedza procentowała w dalszych jego pracach. I jeszcze jedno: przygotowanie summae prusologiae było również szkołą trudnej sztuki sporządzania streszczeń, odnajdywania sedna rzeczy w morzu słów. Stąd (po części) brać się mógł jasny, rzeczowy styl jego narracji.

Wiedza, którą posiadł w trakcie opracowywania Kalendarza, służyła następnie Profesorowi do przygotowania haseł biograficznych w słownikach i leksykonach ${ }^{37}$.

Ważny wydaje się także wkład Fity w pełniejsze poznanie Prusa powieściopisarza. Profesor przyczynił się do lepszego rozumienia Prusowskiego arcydzieła, czyli Lalki. Najpierw w artykule Na marginesach "Lalki” podzielił się obserwacją, że „Prus nieraz w swoich utworach cytował sam siebie, wykorzystywał wcześniejsze pomysły, przetwarzając je stosownie do nowych potrzeb i okoliczności” ${ }^{8} 8$ i z tym zjawiskiem mamy do czynienia także i w tej powieści. Ponadto, wykorzystując kroniki, można ustalić podobieństwo zagadnień i wydarzeń absorbujących za-

36 E. Pieścikowski, Summa prusologiae, „Ruch Literacki” 1979, nr 4, s. 257-258; wyróżn. moje - B.K.O.

37 S. Fita, Prus Bolesław, w: Słownik badaczy literatury polskiej, [zeszyt próbny], red. J. Starnawski, Łódź 1989, s. 31-33; S. Fita, Prus, w: Le Patrimoine Littéraire Européen. Anthologie en langue française, dir. J.-C. Polet, vol. 12: La Mondialisation De L'Europe 1885-1922, Bruxelles 2000, s. 497-512.

38 S. Fita, Na marginesach „Lalki”, w: Nowe stulecie trójcy powieściopisarzy, red. A.Z. Makowiecki, Warszawa 1992, s. 142. 
równo kronikarza, jak i powieściowe postaci (kanalizacja stolicy, zabawy wielkanocne, zawalanie się domów, koncerty skrzypcowe Pabla Sarasatego etc). Lalka wszakże umożliwiła pisarzowi wypowiedzenie tych kwestii, na które w kronikach nie było miejsca bądź z powodu cenzury (sprawy polityczne), bądź z powodu typu uprawianej przez niego felietonistyki (skoncentrowanej na chwili bieżącej i podejmującej tematy, na które Polacy mogą mieć realny wpływ). Pozwoliła mu także w subtelny sposób podzielić się okruchami autobiograficznymi, które stają się widoczne jedynie w rezultacie uważnego czytania korespondencji (np. możliwość życia na emigracji). Nieco inaczej, przez pryzmat stosunku Prusa do przeszłości Polski i Europy, na świat Lalki spojrzał w studium Na drodze do „Lalki”: historia i tradycja w twórczości Bolesława Prusa ${ }^{39}$.

Edycja Lalki w opracowaniu Józefa Bachórza w „Bibliotece Narodowej” została przez Profesora wnikliwie i szczegółowo zrecenzowana na łamach „Pamiętnika Literackiego" ${ }^{\circ}$. Nowe opracowanie zyskało wielką przychylność recenzenta, zwłaszcza rozbudowane, erudycyjne komentarze, ułatwiające lub wręcz umożliwiające swobodą lekturę powieści. Do pełnych aplauzu uwag dołączył wszakże kilka sugerowanych uzupełnień lub sprostowań.

Także Placówka nie pozostała niezauważona przez Profesora Fitę. Przygotował on osobny wybór materiałów służących poznaniu dziejów tekstu ${ }^{41}$. Tym samym powstała monografia dzieła, „opracowana kompetentnie, a pomyślana oryginalnie w ramach przyjętego schematu serii «Z żaczkiem»" "2. Jej lektura pozwala zapoznać się z metodą prac filologicznych Fity: wchodzić w dialog (nierzadko bardzo krytycznie) ze stanem badań, uprzednio pieczołowicie zestawionym, „zsumowywać" dotychczasowe propozycje interpretacyjne, ale referować także własne stanowisko, podawać odczytania nowe, w tym wypadku dotyczące „genezy, rozumianej wielostronnie: jako zespół biograficznych przyczyn sprawczych [...], kompleks poglądów autorskich [...], kontekst historycznoliteracki, [...] proces powstawania wersji ostatecznej (genetyzm immanentny)" ${ }^{43}$ i recepcji utworu. Fita, ku niezadowoleniu krytyków, nie wdał się w próby ustalenia typu powieści (realistyczna, tendencyjna, „dla pokrzepienia serc”), nie analizował konsekwencji dostrzeżonego już wcześniej „rozstania z romansem”, skupił się natomiast na kwestii chłopskiej. Osadzona w poprawnie interpretowanym materiale źródłowym konstelacja wypowiedzi powiązanych z Placówką dziś nabiera dodatkowego wymiaru: adeptom studiów filologicznych, zwłaszcza polonistycznych, uka-

S. Fita, Na drodze do „Lalki”: historia i tradycja w twórczości Bolesława Prusa, w: „Lalka” i inne. Studia w stulecie polskiej powieści realistycznej, red. J. Bachórz, M. Głowiński, Warszawa 1992, s. 29-48. S. Fita, B. Prus, Lalka, t. 1-2, oprac. J. Bachórz, „Pamiętnik Literacki” 1996, z. 4, s. 226-232.

42 E. Pieścikowski, S. Fita, „Placówka” Bolesława Prusa, Warszawa 1980, „Ruch Literacki” 1984, nr 3, s. 205.

43 Tamże. 
zuje zakres i sposób budowania warsztatu historyka literatury, a tylko ów warsztat stanowić może rękojmię uczciwie prowadzonych prac analitycznych i interpretacyjnych.

Co ciekawe, zajmowały Profesora także powieści niepowstałe, których szkice znajdują się w materiałach notatkowych. Zostały one podane i zaprezentowane w wyborze najcelniejszych zapisów oraz skomentowane na tle drukowanych dzieł pisarza ${ }^{44}$.

Dwutomowego wyboru kronik dokonał Profesor pod koniec lat osiemdziesiątych XX wieku. Pierwszym powodem jego przygotowania była chęć udostępnienia tej części spuścizny Prusa szerszemu ogółowi.

Zbiorowe, wielotomowe edycje pism [miał tu na myśli 20-tomową edycję Kronik w opracowaniu Z. Szweykowskiego - B.K.O.] trudniej znajdują czytelników niż odpowiednio przygotowane wybory - pisał. - [...] Motywem wiodącym doboru tekstów jest Warszawa, jej sprawy i ludzie. [...] Chodziło o to, aby dobrać teksty ilustrujące te sfery życia miasta, które były przedmiotem szczególnej troski Prusa. ${ }^{45}$

Wydawca nie tracił przecież z pola widzenia i tych kwestii, które u schyłku XIX wieku i na początku XX wieku zaprzątały uwagę wszystkich Polaków i wielu Europejczyków. Drugi cel stanowiło zapoznanie odbiorców z kształtem dziewiętnastowiecznego felietonu jako gatunku publicystycznego, prasowego. Uwagi na ten temat rozrosły się we wstępie w samodzielną całostkę, zawierającą sporo istotnych ustaleń genologicznych i historycznych dla tej części piśmiennictwa polskiego ${ }^{46}$. Stanisław Fita $\mathrm{z}$ jednej strony podziwiał felietonistykę doby pozytywizmu za wyraźne zaangażowanie społeczne, za walkę „o sprawy pozornie zwykłe i banalne, w rzeczywistości - ważne" ${ }^{47}, \mathrm{z}$ drugiej - za czarodziejskie niemal uwodzenie słowem: dowcipem, humorem, frazą wywołującą współczucie lub zawstydzenie, umiejętnością besztania czy pouczania. I tu znów docenić należy wkład Profesora w poznanie pełnego obrazu Prusa felietonisty, o czym zaświadcza publikacja niedrukowanych kronik tygodniowych ${ }^{48}$.

Praca nad tak zaprojektowanym wyborem kronik umożliwiła Profesorowi przygotowanie obszernego artykułu, w którym analizował obraz Warszawy w twór-

44 S. Fita, Nie zrealizowane pomysły literackie Bolesława Prusa, w: Archiwum Literackie, t. 19, s. 31-41; S. Fita, Nie zrealizowany projekt powieści B. Prusa o niewoli babilońskiej, „Pamiętnik Literacki" 1992, z. 4, s. 147-151.

45 S. Fita, Wstęp, do: B. Prus, Kroniki, oprac. S. Fita, t. 1, Warszawa 1987, s. 17.

46 Została ona przedrukowana w tomie „Pozytywista ewangeliczny”. Studia o Bolesławie Prusie pod tytułem Prus felietonista, s. 235-258.

47 S. Fita, Wstęp, s. 12.

48 S. Fita, Niedrukowane „Kroniki tygodniowe” Bolesława Prusa, „Pamiętnik Literacki” 1976, z. 1, s. 181-205. 
czości Prusa. Wątki sygnalizowane w materiale felietonowym zostały poszerzone o obserwacje zawarte w powieściach i korespondencji ${ }^{49}$.

Stanisława Fitę interesowały zagadnienia relacji łączących Prusa z jemu współczesnymi. Niektórym z nich poświęcił osobne szkice. Scharakteryzował zatem zawiązaną jeszcze w czasach lubelskich przyjaźń z Mścisławem Godlewskim ${ }^{50}$, kontakty z profesorem Henrykiem Struvem (sprowokowane polemiką Kasy im. Józefa Mianowskiego z Wacławem Nałkowskim) ${ }^{51}$, długoletnią znajomość Prusa i Stanisława Witkiewicza (tu zwłaszcza ich poglądy estetyczne i zapatrywania na problem stylu narodowego) ${ }^{52}$, rozpoczęte prasowym sporem o wpływ nauki na stan moralności, a zakończone obopólnym szacunkiem dla dokonań literackich, związki z Adolfem Dygasińskim ${ }^{53}$. Szczególną proweniencję ma szkic Adam Grzymała-Siedlecki o Bolesławie Prusie ${ }^{54}$. Wyrósł on ze swoistego długu Profesora wobec znakomitego krytyka literackiego, wnikliwego czytelnika dzieł Prusa. Zapożyczony z jego spostrzeżeń epitet określający autora Kamizelki: „pozytywista ewangeliczny” nieraz przypisywano Ficie. W ramach rewanżu za owe „subsydium” lubelski badacz przygotował studium poświęcone fascynacji Grzymały-Siedleckiego postacią i dziełem Aleksandra Głowackiego. On też ukazał wyjątkowość osoby i dzieła Prusa na tle światopoglądu definiowanego jako pozytywizm i generacji polskich pozytywistów ${ }^{55}$.

Interesował Profesora również sąd Prusa o przejawach różnych zjawisk społecznych (stąd omówił jego stanowisko w kwestii tzw. „opinii publicznej” i plotki ${ }^{56}$ ), o długofalowych skutkach wydarzeń historycznych (takich jak wypadki 1905 roku ${ }^{57}$, rozbiory Polski, wojny XVII wieku, wiktoria wiedeńska, bitwa pod Grunwaldem) ${ }^{58}$, o racjach angażowania się w politykę i o racjach trzymania się od niej z dala ${ }^{59}$,

S. Fita, Bolesław Prus, w: Warszawa pozytywistów, red. J. Kulczycka-Saloni, E. Ihnatowicz, Warszawa 1992, s. 115-137. Znacznie rozszerzona wersja tego szkicu została następnie pomieszczona w tomie „Pozytywista ewangeliczny”. Studia o Bolesławie Prusie pod tytułem Warszawa Bolesława Prusa, s. 277-311.

50 S. Fita, Bolesław Prus i Mścisław Godlewski, „Twórczość” 1959, nr 12, s. 129-131.

51 S. Fita, Bolesław Prus i Henryk Struve. (Z niedrukowanej korespondencji).

52 S. Fita, Bolesław Prus i Stanisław Witkiewicz, „Przegląd Humanistyczny” 1983, nr 9/10, s. 105-118.

53 S. Fita, Bolesław Prus i Adolf Dygasiński, w: Trzy pokolenia. Pamięci prof. Janiny Kulczyckiej-Saloni, red. A.Z. Makowiecki, Warszawa 1998, s. 63-72.

54 S. Fita, Adam Grzymała-Siedlecki o Bolesławie Prusie, „Poznańskie Studia Polonistyczne” 2000, t. 7, s. 115-124.

55 S. Fita, Bolesław Prus a pozytywizm, s. 41-55.

56 S. Fita, Plotka w twórczości Bolesława Prusa, w: Mieszczanie i mieszczańskość w drugiej połowie XIX wieku, red. E. Ihnatowicz, Warszawa 2000, s. 81-92.

57 S. Fita, Publicystyka B. Prusa w roku 1905, w: Prace o literaturze i teatrze ofiarowane Zygmuntowi Szweykowskiemu, red. J. Maciejewski, Wrocław 1966, s. 197-205.

58 S. Fita, Bolesława Prusa myśli o dawnej Polsce, w: „W krainie pamiątek”. Prace ofiarowane prof. B. Zakrzewskiemu w osiemdziesiąta rocznicę urodzin, red. J. Kolbuszewski, Wrocław 1996, s. 297-308.

59 S. Fita, Poetyka i etyka, w: Bolesław Prus. Pisarz. Publicysta, Myśliciel, Lublin 2003, s. 407-417. 
i o społeczno-politycznej roli wybitnych jednostek ${ }^{60}$. W osobną grupę układają się szkice poświęcone wyprawom Prusa na wschód: do Galicji ${ }^{61}$ i na Wołyń ${ }^{62}$. Znalazły one wspólny mianownik w artykule Bolesław Prus o problemach wschodniego pogranicza ${ }^{63}$.

Fita jest najwnikliwszym jak dotąd badaczem różnorodnych przejawów religijności, które znalazły swój literacki obraz w dziełach autora $Z$ żywotów świętych. Jego obszerny szkic poświęcony problematyce religijnej w twórczości Prusa ${ }^{64}$ nie tylko ukazywał meandry odczytywania „szyfrów Transcendencji” w pismach Głowackiego. Był także w chwili publikacji ważnym sygnałem dowodzącym konieczności i zarazem możliwości penetrowania duchowego wymiaru literatury pozytywistycznej.

Swego rodzaju summa fitologiae w dziedzinie badań nad Prusem to cytowany tu już zbiór studiów „Pozytywista ewangeliczny”, przygotowany na trzy lata przed śmiercią Profesora. To antologia wypowiedzi, które Autor uznał za swój najistotniejszy wkład w rozwój prusologii. Jak widać z niniejszego zestawienia, z konieczności skrótowego, Prus bez rozlicznych zatrudnień Stanisława Fity - edytora, biografa, historyka literatury, dydaktyka, sui generis muzealnika - byłby inaczej obecny w literaturoznawstwie polskim i powszechnym.

Byłby dużo słabiej i dużo gorzej obecny.

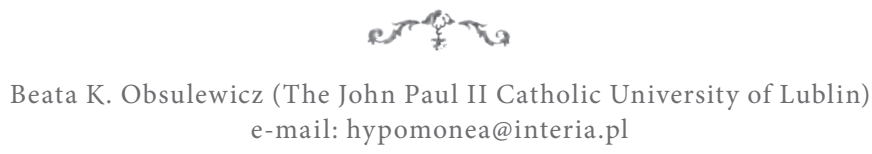

StanisŁaw Fita And Boleseaw Prus

A B S T R A C T

Looking at Stanisław Fita's historical literary output, one will not make a mistake of stating that Bolesław Prus was certainly the most important research area for the Professor. He was also a tool Fita used to study the nineteenth century. Considering the vast complex of themes evoked by Prus's

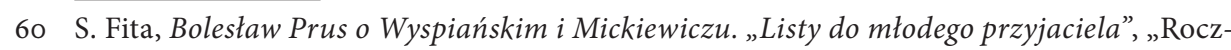
niki Humanistyczne” 1970, z. 1, s. 147-160; S. Fita, Pozytywista o Wyspiańskim, „Ethos” 1999, nr 4, s. 29-41.

61 S. Fita, „Galicyjska misja” Bolesława Prusa, „Pamiętnik Literacki” 1963, z. 1, s. 171-179; S. Fita, Wizyta Bolesława Prusa w lwowskim Ossolineum, „Pamiętnik Literacki” 1985, z. 3, s. 169-173.

62 S. Fita, „Notatki wołyńskie” Bolesława Prusa i jego nieznany list do Henryka Ułaszyna, s. 388392.

63 S. Fita, Bolesław Prus o problemach wschodniego pogranicza, „Prace Filologiczne. Seria Literaturoznawcza" 2008, t. 55, s. 241-248.

64 S. Fita, „Pozytywista ewangeliczny”. Problematyka religijna w twórczości Bolesława Prusa, „Roczniki Humanistyczne”1987, z. 1, s. 5-45; S. Fita, „Pozytywista ewangeliczny”. Problematyka religijna w twórczości Bolesława Prusa, w: Proza polska w kręgu religijnych inspiracji, red. M. Jasińska-Wojtkowska, K. Dybciak, Lublin 1993, s. 159-201. Podobna problematyka - zob. S. Fita, Oblicza Boga w twórczości B. Prusa, „Zeszyty Karmelitańskie” 2002, nr 1, s. 102-110. 
works, he sensitized him to phenomena most important to the Polish culture and social life in the nineteenth and, perhaps, the twentieth century.

KEYWORDS

Bolesław Prus, history of Polish literature, Stanisław Fita

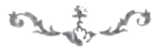

Magdalena Kreft

DOI: $10.18318 /$ wiekxix.2017.34

(Uniwersytet Gdański)

\section{„WyKoŁysana Wodami Niemna” \\ Eliza Orzeszkowa Staniseawa Fity}

Mojemu pierwszemu, a potem także ostatniemu w życiu, spotkaniu z Profesorem Stanisławem Fitą patronowała Eliza Orzeszkowa. Poznałam bowiem Profesora w Białej Podlaskiej pod koniec 2000 roku na konferencji "Literackie obrazy kultury polskiej - twórczość Elizy Orzeszkowej”. Ostatni zaś raz widziałam go w listopadzie 2010 roku w Warszawie na konferencji „Sekrety Orzeszkowej”. Wciąż pamiętam moment, gdy chcąc zdążyć na pociąg, wyszedł z sali, oglądając się za siebie i żegnając zebranych spojrzeniem ${ }^{1}$.

Tytuł zbioru prac ofiarowanych Profesorowi z okazji jubileuszu: Prus i inni, trafnie oddaje specyfikę jego zainteresowań ${ }^{2}$. Chociaż bowiem najważniejszy dla niego był Prus, to owi ,inni” wcale nie niższą mieli rangę w Jego pracach i wcale nie tak mało poświęcał im czasu i uwagi. W gronie „innych” poczesne miejsce zajmowała Eliza Orzeszkowa. Profesor, sam urodzony w Iwiu, niedaleko Niemna, na pewno w jakiś szczególny i osobisty sposób postrzegał krajobrazy z jej powieści oraz pojmował myśli pisarki, na której życie i twórczość wywarła znaczący wpływ właśnie nadniemeńska mała ojczyzna.

Swój naukowy związek z dziedzictwem Elizy Orzeszkowej zasygnalizował mocno już w obszernej recenzji jej Listów zebranych (t. 1-7), napisanej w 1974 roku ${ }^{3}$. Omówienie edycji korespondencji przekształca się u Fity w zajmującą opowieść o pisarce, jej osobowości, różnorodności typów jej listowania, skali stylów, jak i o pracy jej edytora, Edmunda Jankowskiego. Wydaje się, że mało kto, tak jak wykonawca benedyktyńskiej pracy badawczej nad osobą i dziełem Bolesława Prusa, potrafił właściwie zanalizować i docenić żmudną pracę Edmunda Jankowskie-

1 Ostatnim wkładem Stanisława Fity do badań nad twórczością Orzeszkowej jest niewygłoszony wówczas, ale złożony do druku w tomie pokonferencyjnym referat, który ukazał się już po śmierci autora. Zob. S. Fita, Orzeszkowa a powieściopisarze młodopolscy, w: Sekrety Orzeszkowej, red. G. Borkowska, M. Rudkowska, I. Wiśniewska, Warszawa 2012, s. 94-102.

2 Prus i inni. Prace ofiarowane Profesorowi Stanisławowi Ficie, red. J.A. Malik, E. Paczoska, Lublin 2003.

3 S. Fita, E. Orzeszkowa, Listy zebrane. T. 1-7, „Pamiętnik Literacki” 1974, z. 2, s. 352-368. 